\begin{tabular}{|c|c|c|}
\hline$A$ & $\begin{array}{c}\text { International Journal of Current Research } \\
\text { and Academic Review }\end{array}$ & \\
\hline $\begin{array}{l}\text { EXCELLENT } \\
\text { PUBLISHERS }\end{array}$ & 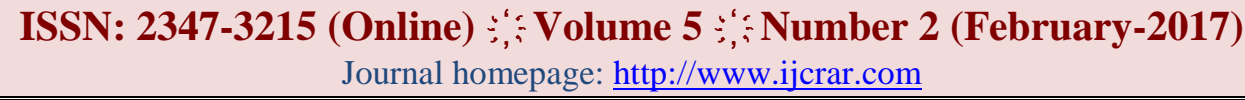 & \\
\hline
\end{tabular}

doi: http://dx.doi.org/10.20546/ijcrar.2017.502.007

\title{
First Record of Fungi and Actinobacteria Isolated from the Marine Sediment Collected in the Intertidal Region from an Island Located in the South of Brazil
}

\author{
Mariana Vieira Porsani ${ }^{1}$, Hedda Elisabeth Kolm² and Ida Chapaval Pimentel ${ }^{1}$ \\ ${ }^{I}$ Basic Pathology Department, Biological Sciences Sector, Federal University of Paraná, Curitiba, Paraná, Brazil \\ ${ }^{2}$ Centre for Marine Studies, Earth Sciences Sector, Federal University of Paraná, Pontal do Sul, Paraná, Brazil
}

*Corresponding author

\section{Abstract}

Mel Island is considered a Natural Historic Site of Paraná State, South Brazil, with approximately 2,760 ha, of which about $95 \%$ are protected as the Ecological Station and State Park. This is the first record that evaluates the presence of actinobacteria and fungi in this environment. This research studied the spatial variability of fungi and actinobacteria in the surface of fifteen intertidal stations in Mel Island, Brazil. The number of organisms was compared in relation to physical-chemical factors. We isolated 332 microorganisms. The results showed significance in the temperature of the sediments related to the time of the day on which sample was collected. There were significant differences in the amount of cultivated fungi and actinobacteria. The Principal Component Analysis (PCA) showed that there was an inverse correlation between the number of microorganisms and the temperature. The grain size and organic matter sediment did not interfere in the amount of fungi and actinobacteria. The results show the expansion of the knowledge about the microbiology in the regions between tides furthermore, this microorganisms collected from marine sediment can hold great promise as biological control agents and they might show ability to produce undescribed bioactive compounds yet.
\end{abstract}

\section{Article Info}

Accepted: 25 January 2017

Available Online: 20 February 2017

\section{Keywords}

Actinobacteria, Marine sediment

\section{Introduction}

Tourism is an activity that, in principle, assumes the possibility of reconciling environmental conservation and income generation for local communities. However, this activity is expanding rapidly and in a disorderly way in many places along the Brazilian coast leading to degradation of the environment (Kim, 2004).

The occurrence of microorganisms in beach sands frequented by swimmers and fishermen can lead to high levels of pollution and according to the rapid occupation of the coastline Mel Island. In recent decades several issues aimed at environmental preservation have emerged, or were detected in protected areas (ObiriDanso and Jones, 2000). The microorganisms spread over many different environments and depths, as they have an amazing ability to adapt. Withstand temperatures between -5 and $60^{\circ} \mathrm{C}$, very acidic or alkaline, brackish and even little oxygen, a concentration of $0.25 \%$, while the atmosphere has $20 \%$ oxygen (Romminger, 2006).

Marine fungi grow and reproduce exclusively or preferentially at the sea, or when the salt concentration 
remains within normal limits, i.e. between 25 and $40 \%$ (Meyers, 1968). They are the tolerant haloforms of limnic and terrestrial origin, being that filamentous fungi that colonize marine environments are mainly saprophytic. Most of them are found in coastal environments settling on particulate organic matter present in water and sediment (Kohlmeyer, 1968; Kohlmeyer and Kohlmeyer, 1979; Rheinheimer, 1987).

Several factors such as origin, nature of the substrate, salinity and $\mathrm{pH}$ can affect the complex ecosystem diversity of fungi in the marine environment because it is a wide variation in many parameters; therefore, has no distribution pattern of fungi in different geographic regions (Babu et al., 2010). Moreover, this transition environment between land and sea is where the occur actinobacteria. The phylum and class Actinobacteria share important characteristics, all are Gram-positive, have a high ratio of guanine/cytosine in their DNA, they may exceed $70 \%$ of nucleotide bases, ranging from $51 \%$ in Corynebacteria and more than $70 \%$ in Streptomyces and Frankia (Holt et al., 2004).

Bacteria belonging to the class Actinobacteria commonly reported in marine environments are mainly of three genera: Micromonospora, Rhodococcus and Streptomyces. Many isolates represent new species and, therefore, potential innovative sources of bioactive compounds (Maldonado et al., 2005).

Actinobacteria exhibit various physiological and metabolic properties such as the production of extracellular enzymes further the formation of a wide variety of secondary metabolites including some antibiotics in use today are derived from natural actinobacteria and fungi products (Raju et al., 2010; Porsani, et al., 2013; Manivasagan et al., 2014; Sathiyanarayanan et al., 2014; Rashad et al., 2015; Romano et al., 2016; Dalitz, et al., 2016; Alvarez et al., 2017). In addition, different styles of life are found among actinobacteria thus this phylum includes pathogens (eg. Mycobacterium spp., Nocardia spp., Tropheryma spp., Corynebacterium.spp and Propionibacterium spp.), the inhabitants of the soil (Streptomyces spp.), dinners plant (Leifsonia spp.), nitrogen-fixing symbionts (Frankia), and from gastrointestinal tract (Bifidobacterium spp.) (Ventura et al., 2007).

Mel Island is considered a Natural Historic Site of Paraná State, South Brazil, with approximately 2,760 ha, of which about $95 \%$ are protected as the Ecological
Station State Park and this is the first study that aimed to isolate fungi and actinobacteria from the intertidal region of Mel Island. The results were compared with the physical and chemical factors of each site sampled to verify if different areas were affected by environmental parameters.

\section{Materials and Methods}

\section{Study area}

The study area comprises the Paranaguá Bay Estuarine

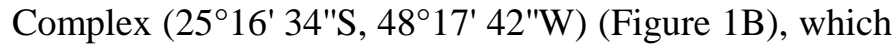
is the largest estuary in Paraná State (Figure 1A) and it extends about $50 \mathrm{~km}$ inland. Mel Island (Figure C) is located at the entrance of Paranaguá Bay, on the northern coast of Paraná (Marque and Britez, 2005) and is separated from the mainland (Ponta Inacio Dias in Pontal do Sul) for approximately 2,800 meters.

\section{Sample collections}

Samples were collected on February 1 and 2, 2007, between 7 and 11 am (from the end of the ebb and beginning of syzygy flood). Surface sediment was collected (2-3 cm depth) on intertidal regions in fifteen stations distributed around the entire length of the Mel Island (Figure C). All samples were collected at two different points A and B (one closest to the waterline and another further away).

\section{Abiotic parameters}

The following abiotic parameters were analyzed: temperature of the sediment measured in the field with standard thermometer scale $1 / 100^{\circ} \mathrm{C}$, and granulometry, organic matter and calcium carbonate in the sediment was analyzed according to the Suguio (1973) methodology modified by Zem (2005). To calculate the moisture content it was measured by weight difference before and after drying the sample for 24 hours at $70^{\circ} \mathrm{C}$. Sub-dried samples were burned at $550^{\circ} \mathrm{C}$ for 60 minutes for the determination of organic matter and $1000^{\circ} \mathrm{C}$ for $60 \mathrm{~min}$ for the determination of calcium carbonate.

\section{Isolation and identification of filamentous fungi and actinobacteria}

The amount of $15 \mathrm{~cm}^{3}$ of sediment was measured for isolation of filamentous fungi and actinobacteria with the aid of plastic syringes with the ends split and collected with disposable spoons. The samples were placed in 250 
$\mathrm{ml}$ Erlenmeyer flasks previously sterilized and diluted with $135 \mathrm{ml}$ of distilled water.

The bottles were agitated in a shaker for 10 minutes at 80 $\mathrm{rpm}$ and the sediment decanted for 10 minutes (Kolm, 1999). Then $2.0 \mathrm{ml}$ were removed from the supernatant of which $1 \mathrm{ml}$ was distributed in 5 Petri dishes $(0.2 \mathrm{ml}$ per dish) with Czapeck-dox medium and $1 \mathrm{ml}$ in 5 dishes (0.2 mL per plate) containing Czapeck-dox medium with the addition of seawater. The solution was spread on the plates with the aid of Drigaslki handles and incubated at $28^{\circ} \mathrm{C}$ for a maximum of 7 days.

After isolation, a counting of the number of colonies of filamentous fungi and actinobacteria was performed and the result was expressed in CFU. $\mathrm{mL}^{-1}$. Subsequently, the colonies were purified and transferred to test tubes and are currently deposited in the biological banking of the Microbiology and Molecular Biology Laboratory (LabMicro) of the Basic Pathology Department, Federal University of Paraná. For identification of filamentous fungi and actinobacteria macroscopic characteristics of the isolated colonies were evaluated: color (surface, reverse, edges and middle), texture, consistency. The micro culture was performed (Kern and Blevins, 1999) for further identification by observation of the microscopic structures of reproduction (sexual and asexual), according to the specialized literature. The Gram coloration also was performed to visualize microstructures of actinobacteria (Ellis, 1976; Barnett and Hunter, 1972; Arx, 1974; Koneman and Roberts 1987; Larone, 1987; Rossman et al., 1987; Siveira, 1995; de Hoog and Guarro, 2004).

\section{Statistical analysis}

The results were submitted to ANOVA and Principal Component Analysis (PCA) using the package STATISTICA (StatSoft Inc.) For the Principal Component Analysis the data were transformed to $(\log \mathrm{X}$ $+0.1)$. The results, while significant, were presented in the form of graphs and the analysis of variance, the "F" values, the degrees of freedom and "p" was inserted in each figure. When not significant, the values of $F$ and $p$ were inserted in the text.

\section{Results and Discussion}

\section{Abiotic Parameters}

In relation to the physic-chemical analysis, the results are shown in figure 2 . The lowest temperatures were recorded at stations 1,2 and 10 . The minimum $\left(25.8^{\circ} \mathrm{C}\right)$ was observed at station 2 (point $\mathrm{B}$ ) and maximum $\left(35.0^{\circ} \mathrm{C}\right.$ ) at station 9 (point A) (Figure 2).

There was a significant variation in the temperature of the sediment with higher values mainly at station 9 (Figure 2).

With the exception of the station 13 (point A), consisting of $96.98 \%$ sand, all grain size analysis showed that the analyzed sediments consisted of $100 \%$ sand. The sediment of station 13 also consisted of $1.008 \%$ to $2.015 \%$ silt and clay (Figure 3).

The ANOVA showed no significant variation in grain size of sand $[F(14,5)=1, p=0.4976]$ and silt. It was not possible to analyze statistically the clay due the very low values obtained.

The highest percentage of calcium carbonate $(3.99 \%)$ can be seen in station 7 (point A) and lower $(0.847 \%)$ at station 9 (point A) (Figure 3), however, the ANOVA showed that there was no significant difference ( $F$ $(14,15)=1.5854, \mathrm{p}=0.1931)$.

In figure 3 is observed that the higher organic matter content $(1.042 \%)$ was found at station 13 (point B) and the lowest $(0.169 \%)$ at station 5 (point B), however there is a significant difference in the matter content stations in the organic variation was not significant ( $F$ (14.15) $=2.1683, \mathrm{p}=0.0746$ ).

Likewise, in culture medium, which used fresh water, as many fungi (30 CFU.mL ${ }^{-1}$ ) and actinobacteria (86 CFU. $\mathrm{mL}^{-1}$ ) were isolated from station 3 (point A and B). There were no fungi and/or actinobacteria at stations 10 (points $\mathrm{A}$ and $\mathrm{B}$ ) and 15 (points $\mathrm{A}$ and $\mathrm{B}$ ).

As it can be observed in the figure 4, the greatest number (55 CFU.mL ${ }^{-1}$ ) of fungi and actinobacteria isolated and cultivated with seawater was found at station 3 (point A) in station 5 (point B), 6 (point B), 7 (points $A$ and B), 8 (point A), 9 (point B), 10 (point A), 13 (point B), 14 (point B). 15 (points A and B) were not found both actinobacteria and fungi.

Analysis of variance showed that both culture, with saline and fresh water ranged in the number of fungi and actinobacteria between the sampling stations with the highest values at station $3\left(115 \mathrm{CFU} \cdot \mathrm{mL}^{-1}\right)$ (Figure 5A and B). 
The first component of Principal Component Analysis (PCA) represents $42 \%$ of the variability and it was positively correlated to sand at stations 5, 8, 9 and 11 and positive correlation of silt, clay and organic matter at station 13 . The second component represents $21 \%$ of the variability and was positively correlated whit fungi and actinobacteria isolated in two culture media in stations 1 , 2, 3 and 4 and to a lesser extent the station 12. Negative correlation of fungi and actinobacteria and positive temperature and calcium carbonate were observed at station 15 and to a lesser extent at stations 6, 7, 10 and 14 (Figure 6).

\section{Isolation and identification of filamentous fungi and actinobacteria}

In the present study 332 microorganisms were isolated, of which 197 were fungi and 135 were actinobacteria from nineteen genera Acremonium, Alternaria, Aspergillus, Cladosporium, Dendryphiella, Drechslera, Exophialla, Fusarium, Geotrichum, Humicola, Mycelia sterilia, Monicillium, Orbimyces, Paecilomyces, Penicillium, Rhizoctonia, Trichoderma, Streptomyces and Nocardia.

The number of filamentous fungi and actinobacteria isolated from both culture medium with fresh water and sea water were 152 and $153 \mathrm{CFU}$ respectively. The largest number of microorganisms was isolated in Station 3 (115 CFU. $\left.\mathrm{mL}^{-1}\right)$, followed by station 8 (25 CFU. $\left.\mathrm{mL}^{-1}\right)$. The genus with higher frequencies were Streptomyces, present in greater numbers in station $3\left(56\right.$ CFU. $\left.\mathrm{mL}^{-1}\right)$, Aspergillus in station $3\left(14 \mathrm{CFU} \cdot \mathrm{mL}^{-1}\right)$, Acremonium in station 8 ( 8 CFU. $\left.\mathrm{mL}^{-1}\right)$, Drechslera in station $8(5$ CFU.mL ${ }^{-1}$ ) and Nocardia in station 2 (5 CFU. $\left.\mathrm{mL}^{-1}\right)$ (Figure 4).

There was a great variation in temperature of the sediment with the lowest values recorded at stations 1 (points A and B), 2 (points A and B) and 10 (points A and B). We collected samples on subsequent days to collect the material during the late ebb and early flood, starting the morning and ending around midday. The temperatures variation showed the passing of the hours, with minimum values recorded for the first time and gradually increasing.

This is the first record that filamentous fungi and actinobacteria were isolated from the sediment surface of the Mel Island.The results revealed that many filamentous fungi and actinobacteria were able to grow in culture media prepared with both freshwater and marine water. This shows that, although they originate in the terrestrial environment, they are halotolerant and have the ability to sporulate in seawater. It is important to highlight that the genera Acremonium, Dendryphiella, Exophialla, Humicola, Mycelia sterilia, Nocardia, Paecilomyces, were only found in the culture medium prepared with fresh water and the genera Alternaria, Aspergillus and Drechslera, were only isolated in culture medium prepared with seawater.

The genus with higher frequency in this research was Aspergillus. The Aspergillus species are among the most common fungal isolates from terrestrial, freshwater and marine environments, even from deep-sea sediments. Some are active and partially adapted to aquatic habitats. Conversely, truly aquatic fungi have been found active in several terrestrial habitats (Wurzbacher, et. al., 2010).

Among the genera observed, there is Trichoderma, which is found in many habitats and often isolated from muddy marine sediments. The fungi from the genus Humicola can be found in areas of intertidal and Cladosporium sp. and Dendryphiella arenaria, brackish and marine sediments. Dendryphiella salina and Alternaria are commonly reported as saprophytes of marine algae (Booth, 1979).

From the pathogenic fungi found, the genus Fusarium is highlighted, as associated with shells in sick marine crustaceans and fungal infections in hermit crabs (Hyde et al., 1990).

In marine sediment samples collected in the tropical waters of the North Pacific, the

Caribbean and Costa Rica showed a higher diversity of actinobacteria, both in terms of number of species as phylogenetic composition, with large numbers of the genus Streptomyces (Solano et al., 2009).

In this study the actinobacteria was isolated mainly in station 3 (points $A$ and $B$ ). The importance of actinobacteria in the environment is the degradation of organic matter, because they have proteolytic activity, according to the decomposition of keratin, chitin, cellulose, starch and also the cycle of nitrogen and amino acids (Melo, 2009).

In this research beyond those found at station 3, were still frequent in stations 1,2 and 4 . The results found may be due to the fact that these stations are located near the Southeastern Channel, which drains water coming mainly from the northern sector of the estuary (the 
Fig.1 A) Location of Parana State in Brazil (Source: The author), B) Estuarine Complex of Paranaguá and Mel Island location (Source: The author); C) Mel Island, with location of sampling stations (Source: Britez and Marques [20] modified by Miquelante (2007)

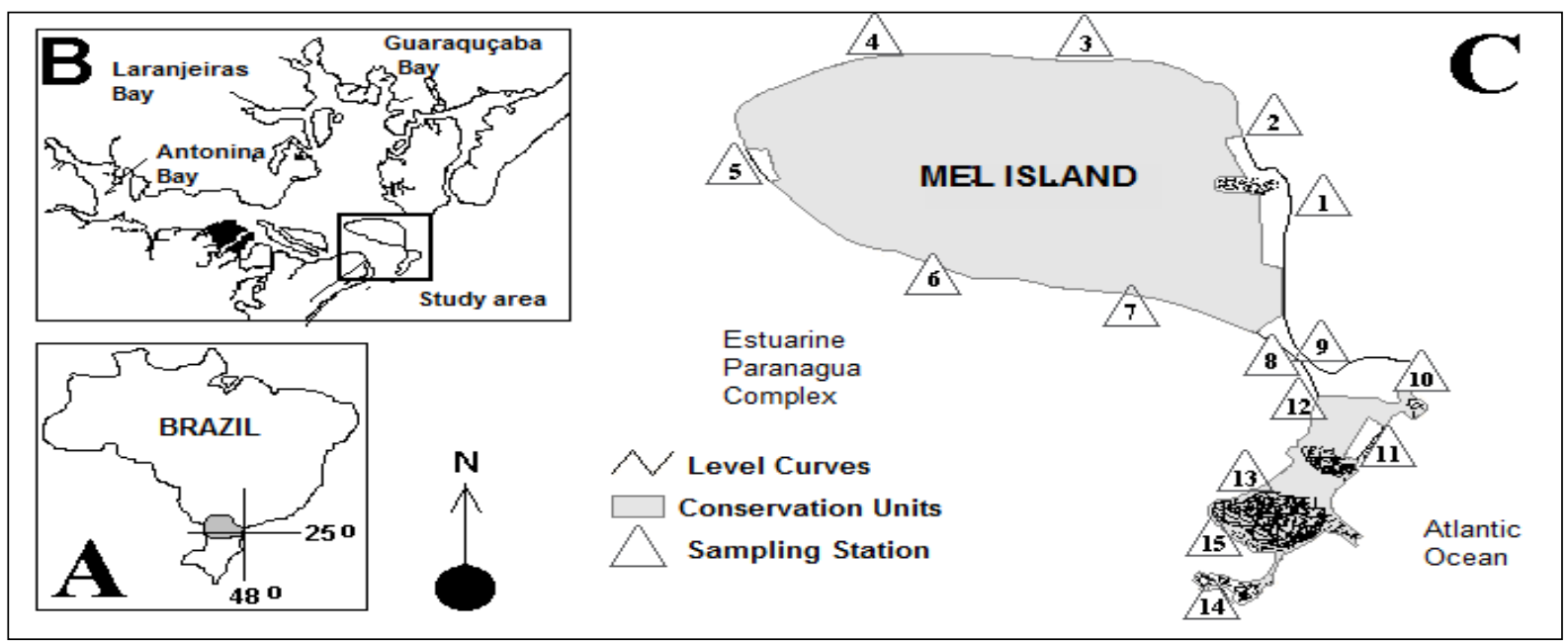

Fig.2 Percentage of temperature in the surface sediments and analysis of variance of the temperature in the fifteen sampling stations of the intertidal area at Mel Island in two spots (A and B)
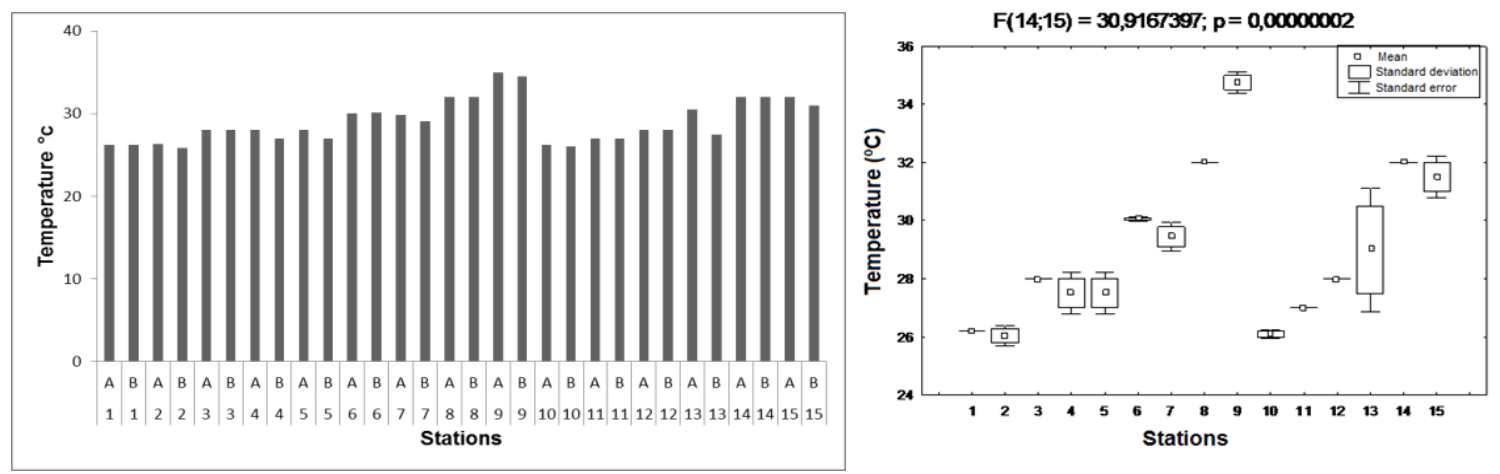

Fig.3 Percentage of sand, silt, clay, calcium carbonate and organic matter sediment of the fifteen stations in two spots (A and B) from intertidal region of Mel Island
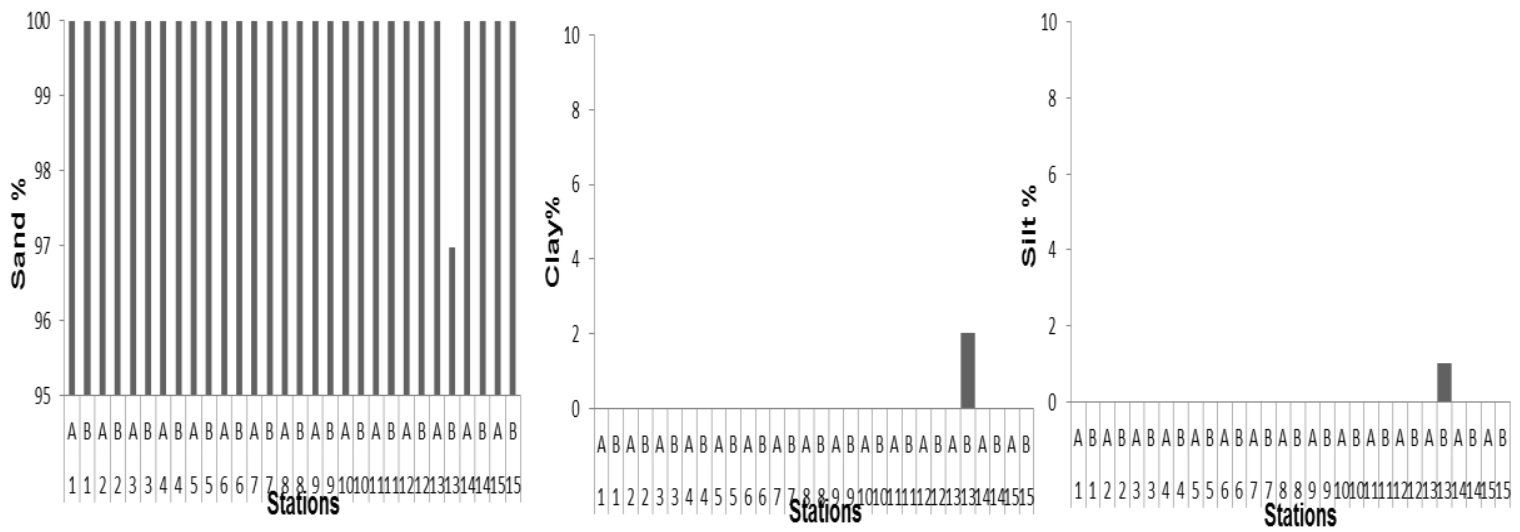

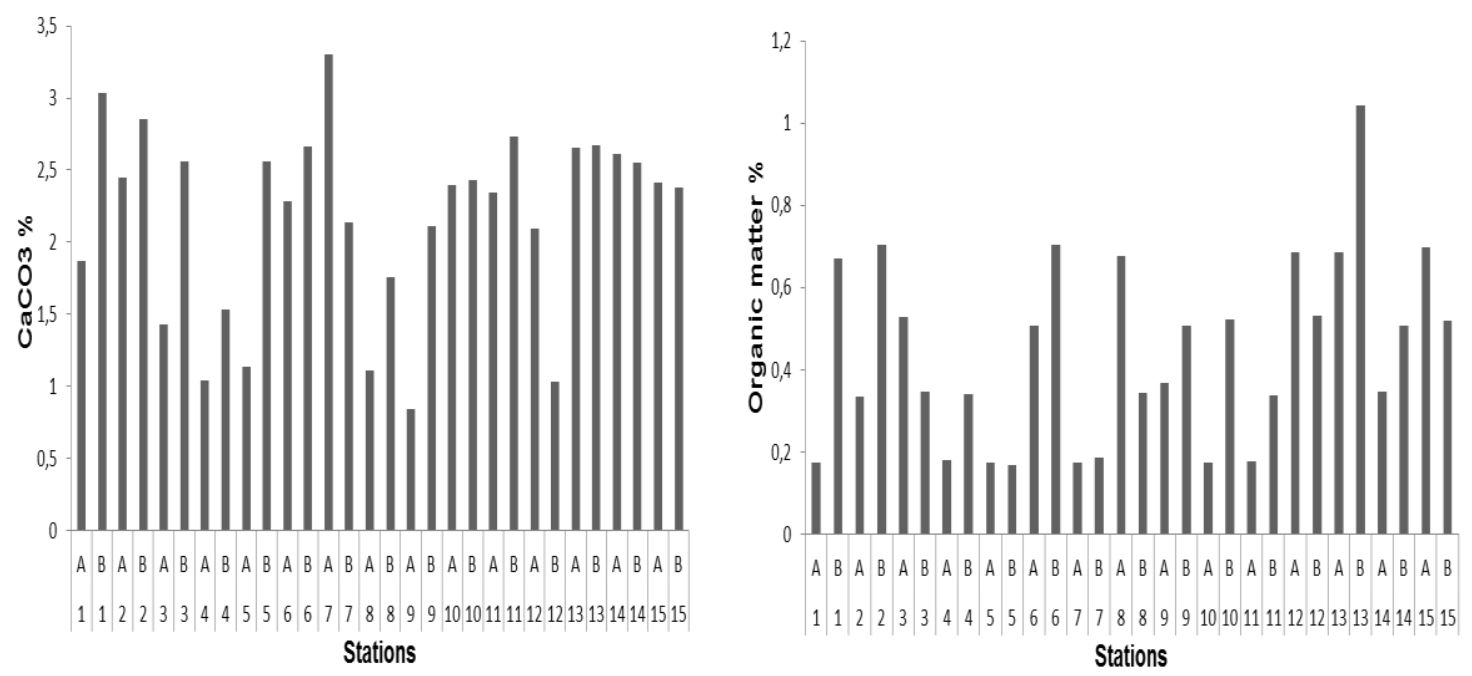

Fig.4 Number of cultivated fungi and actinobacteria in fresh and seawater in two spots (A and B) in the fifteen collect stations in the intertidal region at Mel Island

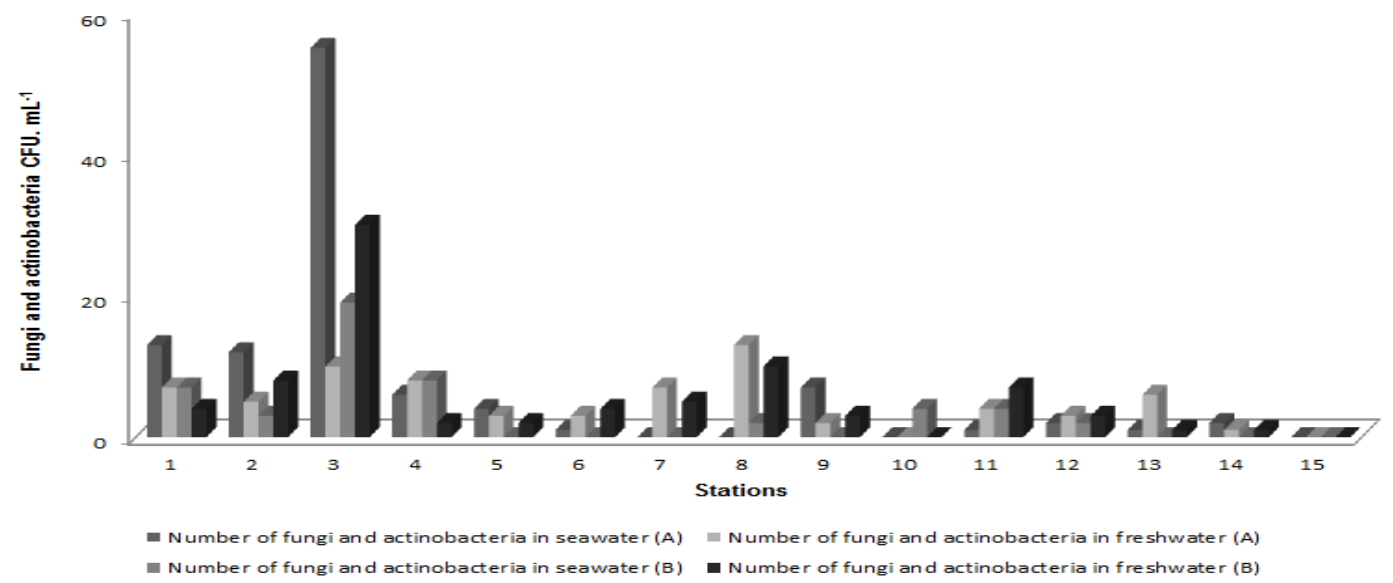

Fig.5 Analysis of variance of the number of fungi and actinobacteria grown: A) in culture made with fresh water and B) culture medium made with seawater in fifteen sampling stations in the intertidal region in Mel Island
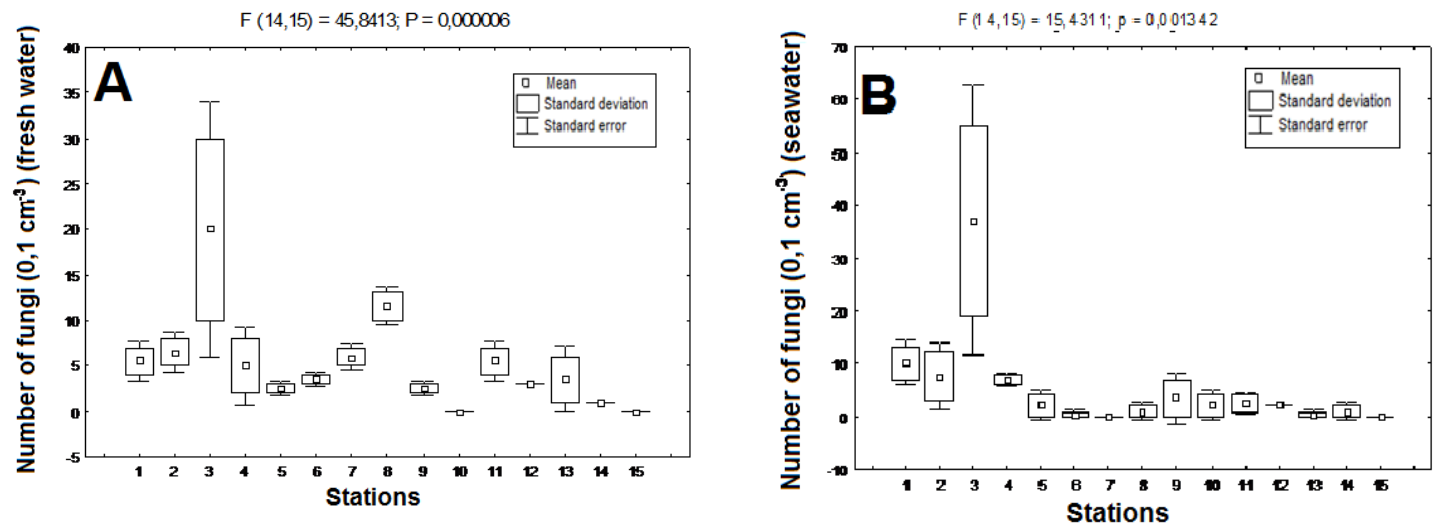
Fig.6 Graphical representation of the Principal Component Analysis in which the following factors were compared: temperature in the surface sediments, sand, silt, clay, calcium carbonate and organic matter sediment and number of cultivated fungi and actinobacteria in the fifteen collect stations in the intertidal region at Mel Island

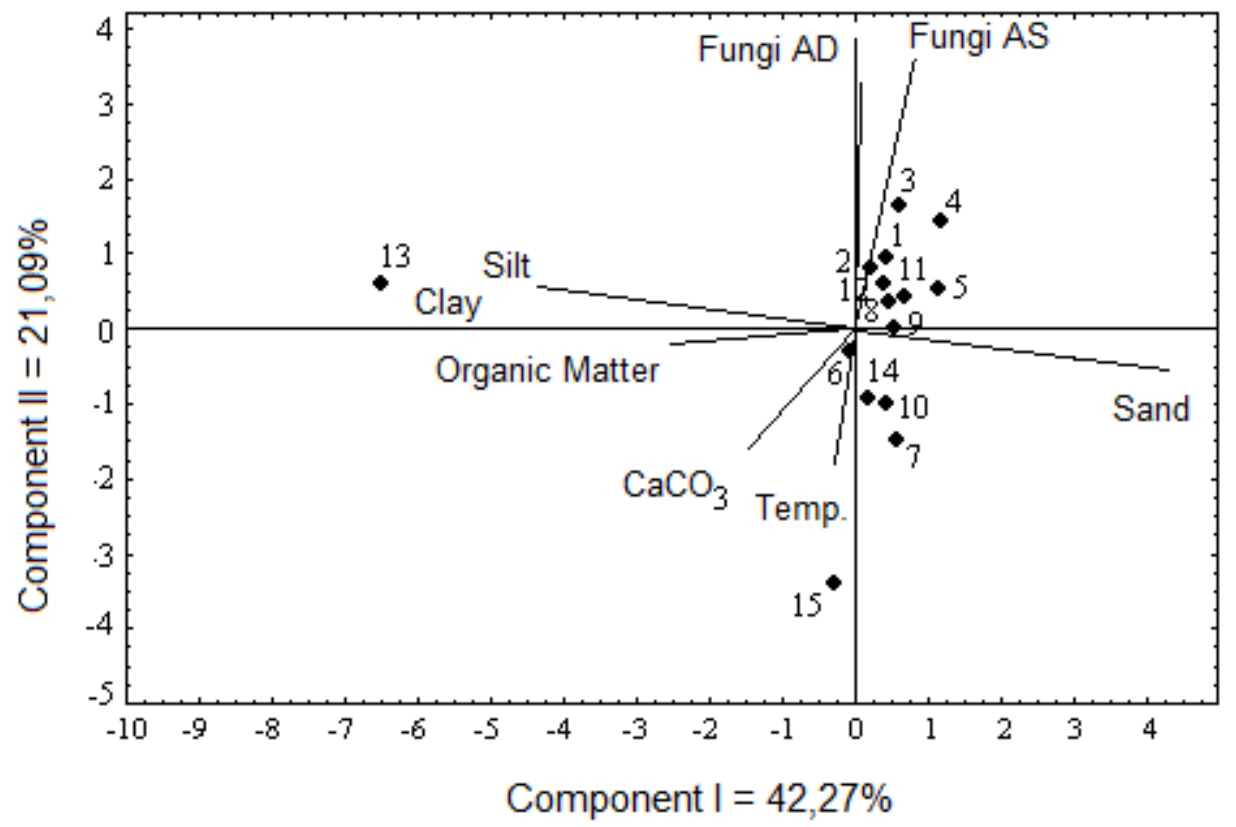

Laranjeiras and Guaraqueçaba bays and Benito's coves). In the northern sector are all protected areas (Superagüi National Park, Guaraqueçaba Environmental Protection Area) from the estuarine complex. This area shows deposition of organic matter in the sediment, providing to the actinobacteria a conducive environment to their development.

Yet it is noteworthy that in studies conducted by the Environmental Institute of Paraná (IAP) (2007), the Mel Island region in which are the stations 3 and 4 , is considered of excellent quality for bathing. Moreover, Miquelante (2007), who made simultaneous collections in the same stations found very low amounts of E. coli in the sediments.

On the other hand, stations 1 and 7, where the diversity of fungi was slightly smaller than the above stations, the water quality was considered to be very good.

However, it should be highlighted the station 8 (especially in point B), which was recorded not only quantity, but also the greatest diversity of them. This station is located in a region of the Saco do Limoeiro where the water has a high residence time and lower energy compared to other locations, suggesting that fungi and actinobacteria sediments of the intertidal area are washed away with less intensity.
The only place where fungi and/or actinobacteria were not found was the $15^{\text {th }}$ station. Along with this station is located the fishing village (Encantadas) with restaurants and lodges built close to the seafront. There is a pier for boats located in an artificial channel that was dredged and whose sediments were deposited on the sides and formed sandbars. This site is also characterized by a very frequent number of tourists and all the typical vegetation of this region has been removed. The absence of fungi in this station may be indicative of the presence of pollutants due to the large anthropogenic influence that inhibit their growth and development.

There is only one study done with fungi of the intertidal area in Paraná State. Guizelini (2002) studied the spatial variability of fungi in the region of three intertidal stations along the Gamboa of Perequê in Pontal do Sul. The author found fungi from the genus Aspergillus, Penicillium, Fusarium, Trichoderma, Acremonium, Chaetomium, Aspergillus niger species and dematiaceous fungi. This is due to several factors such as the large difference in particle size, the greater presence of organic matter, vegetation area closer to the sampling stations and because the study area is located more internally and therefore is less influenced by water adjacent inner continental shelf. However, most of the genera registered in Guizelini (2002) is coincident with the present research. 
The microorganism's communities that are present in regions of intertidal marine environments perform processes that contribute to the functioning of coastal areas, such as the cycling of carbon and also the transfer of metal and organic pollutant removal for trophic levels higher (Ortega-Morales et al., 2010). Thus, the correspondence analysis revealed that seawater samples in different areas were affected by environmental parameters (Dong et al., 2014). Additionally, marinederived filamentous fungi and bacteria represent a promising source of microbial genetic resource to be biotechnologically explored (Menezes et al., 2010; Pang et al., 2016).

It is imperative to obtain data on the distribution of fungi and actinobacteria from intertidal regions, due to environmental importance which occur natural and human disturbances induced moreover this microorganisms can hold great promise as biological control agents (Lira et al., 2006) and source of bioactive molecules (Romano et al., 2016; Alvarez et al., 2017). By the fact of them are exposed to high salinity, temperature, U.V. radiation, and low nutrient levels, they have physiological adaptations that can promote the production of toxins and enzymes, which enable their survival in this hostile environment (Ortega-Morales et al., 2010). Because of these characteristics, this microorganisms may be promising agents for the control of agricultural pests (Lira et al., 2006; Alvarez et al., 2017), nematicidal and phytohormone (Rashad et al., 2015), antifungal and antibiotic activity (Porsani et al., 2013; Dalitz et al., 2016).

The presence of fungal and actinobacterias spores have been blown by the wind from the vegetated areas to the intertidal regions, because the absence of fungi in the station fifteen can be related to this fact. This work shows the expansion of knowledge about the microbiology of intertidal regions. In addition, this microorganisms collected from marine sediment have potential to production compounds with promising biological activities and they might show ability to produce undescribed bioactive compounds yet.

\section{References}

Alvarez, A., Saez, J. M., Costa, J. S. D., Colin, V. L., Fuentes, M. S., Cuozzo, S. A., Benimeli, C. S., Poltri, M. A. and Amoroso, M. J. 2017. Actinobacteria: Current research and perspectives for bioremediation of pesticides and heavy metals. Chemosphere. 166: 41-62.
Arx, J. A. Von. 1974.The Genera of fungi sporulation in pure culture. Vanduz: J. Cramer.

Athayde, S. F. and Tomaz, L. M. 1995. Áreas Naturais Protegidas e Comunidades Locais da Ilha do Mel, PR - Brasil. Nerítica. 9: 49-91.

Babu, R., Varadharajan, D., Soundarapandian, P. and Balasubramaniam, R. 2010. Fungi Diversity in Different Coastal Marine Ecosystem along South East Coast of India. International Journal of Microbiological Research. 1(3): 175-178.

Barnett, H. C. and Hunter, B. B. 1972.Illustrated genera of imperfct fungi. third. ed. Mineapolis: Burgess Publ.

Booth, T. 1979.Strategies for study of fungi in marine and marine influenced ecosystems. Rev. Microbiol. 10(4): 123-138.

Couto, E. C. G. 1996. Spatial-Temporal Structure of the Macrobêntic Community of the Intertidal Plain of Saco do Limoeiro - Mel Island (Parana, Brazil). Ph.D Thesis, Federal University of Parana, Brazil.

Dalitz, C. A.; Porsani, M. V.; Figel, I. C.; Pimentel, I. C.; Dalzoto, P. R. 2016. Potential for biocontrol of melanized fungi by actinobacteria isolted from intertidal region of Ilha do Mel, Parana, Brazil. Brazilian Journal of Microbiology. Article in press.

De Hoog, G. S. and Guarro, J. 2004. Atlas of Clinical Fungi. Centraalbureau voor Schimelcultures/Universitat Rovira i Virgili.

Dong, Y.I., Zhao, Y., Zhang, W., Li, Y., Zhou, F., Liu, C., Wu, Y., Liu, S.; Zhang, W. and Xiao, T. 2014. Bacterial diversity and community structure in the East China Sea by 454 sequencing of the $16 \mathrm{~S}$ rRNA gene. Chinese Journal of Oceanology and Limnology. 32(3): 527-541.

Ellis, M. B. 1976. More Dematiaceous Hyphomycetes. CAB International Mycological Institute, Kew, UK., pp 507.

Environmental Institute of Parana (IAP). Site accessed: february 2007. http//:www.iap.pr.gov.br

Guizelini, A. M. 2002. Quantitative analysis of fungi of the Municipal Park of the Manguezal of Gamboa do Perequê, Paraná, Brazil. Thesis, Federal University of Parana, Brazil.

Holt, J.; Krieg, N. R.; Sneath, P. H. A. 2004.Bergey's Manual of Systematic Bacteriology: The Proteobacteria. Baltimore: Williams and Wilkins.

Hyde, K. D., Jones, E. B. G., Leaño, E., Pointing, S. B., Poonyth, A. D. and Vrijmoed, L. L. P. 1990. Role of fungi marine ecosystems. Biodiversity and Consevation. 7: 1147-1161. 
Kern, M. E., Blevins, K. S. 1999. Micologia médica Texto e Atlas. second ed, São Paulo: Editoral Premier.

Kim, M. K. 2004. Sustainability evaluation of the current development model in Mel Island. Thesis in oceanography. Sea study center. Earth Sciences sector, Federal University of Parana, Brazil.

Kohlmeyer, J. 1968.A new Trematosphaeria from roots of Rhizophora racemosa. Mycopathogens Mycology Applied. 34: 1-5.

Kohlmeyer, J and Kohlmeyer, E. 1979. Marine Mycology: The Higher Fungi. New York, London: Academic Press.

Kolm, H. E and Siqueira, A. 1999. Bacteria variation due to the dredging of the access channel to the Port of Paranaguá, Paraná.Pontal do Sul: CEM. In: Final reporter of research activities in marine microbioly laboratory. Sea study center. Earth Sciences sector, Federal University of Parana, Brazil.

Koneman, E. W. and Roberts, G. D. 1987. Micologia Prática de Laboratório. Buenos Aires: Editora Médica Panamericana.

Larone, D. H. 1987. Medically important fungi: a guide to identification. New York: Elsevier.

Lira, S. P., Vita-Marques, A. V., Seleghim, M. H. R., Bugni, T. S., Sabarbera, D. V., Sette, L. D., Sponchado, S. R. P., Ireland, C. M., and Berlinck, R. G. S. 2006.New Destruxins from the Marinederived Fungus Beauveria felina. Journal Antibiotics. 59: 553-563.

Maldonado, L. A., Stach, J. E. M., Pathom, Ward, A. C., Bull, A. T. and Goodfelow, M. 2005. Diversity of cultivable actinobacteria in geographically widespread marine sediments. Antonie van Leeuwenhoek. 87: 11-18.

Manivasagan, P., Venkatesan, J. and Sivakumar, K.; Kim, S. 2014. Pharmaceutically active secondary metabolites of marine actinobacteria. Microbiological Research.169(4): 262-278.

Marques, M. C. M. and Britez, R. M. 2005. História Natural e conservação da Ilha do Mel. Curitiba: Editora UFPR, Brazil.

Melo, F. M. P. 2009. Bioprospecting of corn rhizosphere actinobacteria (Zea mays) with antifungal activity.Ph.D. Thesis São Paulo University, Brazil.

Menezes, C. B. A., Bonugli-Santos, R. C., Miqueletto, P. B., Passarini, M. R. Z., Silva, C. H. D., Justo, M. R., Leal, R. R., Fantinatti-Garboggini, F., Oliveira, V. M., Berlinck, R. G. S. and Sette, L. D. 2010. Microbial diversity associated with algae, ascidian and sponges from the north coast of São Paulo state, Brazil. Microbiological Research. 165: 466482.

Meyers, S. P. Observations on the physiological ecology of marine fungi. In: Kadota, H and Taga, N. 1968. Proceedings of the US-Japan Seminar of marine microbiology. Bull. Misaki Marine Biology Institute Kyoto University. 12: 207-225.

Miquelante, F. A. 2007. Distribution of total heterotrophic bacteria, total coliforms and Escherichia coli in surface sediments of the intertidal region of Mel Island, Paraná. Thesis in oceanography. Sea study center. Earth Sciences sector, Federal University of Parana, Brazil.

Obiri-Danso, K. and Jones, K. 2000. Intertidal sediments as reservoirs for hippurate negative Campylobacters, Salmonellae and faecal indicators in three EU recognised bathing waters in North West England. Water Research. 34(2): 519-527.

Ortega-Morales, B. O., Chan-Bacab, M. J., Rosa-Garcia, S. C. and Camacho-Chab, J. C. 2010. Valuable processes and products from marine intertidal microbial communities. Current Opinion in Biotechnology. 21: 346-352.

Pang, K., Overy, D., Jones, G., E. B., Calado, M. L., Burgaud, G., Walker, A. K., Johnson, R. G. K., Cha, H. J. and Bills, G. 2016. Marine fungi' and 'marine-derived fungi' in natural product chemistry research: Toward a new consensual definition. British Mycological Society.

Porsani, M. V., Amatuzzi, R. F., Oliveira, B. H., Baratto, L. C., Dalitz, C. A., Bozza, A., Marangoni, P. R., Dalzoto, P. R., Kolm, H. E., and Pimentel, I. C. 2013. Antimicrobial potential of fungi and actinobacteria isolated from Sandy sediments of intertidal regions. International Journal of Pharmaceutical, Chemical and Biological Sciences. 3: 899-913.

Raju, A., Piggott, A. M., Conte, M.; Tnimov, Z., Alexandrov, K. and Capon, R. J. 2010. Nocardiopsins: New FKBP12-Binding Macrolide Polyketides from an Australian Marine-Derived Actinomycete, Nocardiopsis sp. Chemistry European Journal. 16: 3194 - 3200.

Rashad, F.M., Fathy, H. M., El-Zayat, A. and Elghonaimy, A. M. 2015.Isolation and characterization of multifunctional Streptomyces species with antimicrobial, nematicidal and phytohormone activities from marine environments in Egypt. Microbiological Research. 175: 34-47.

Rheinheimer, G. 1987. Microbiologia de Las Aguas. 4. ed. Zaragoza, Espanha: Editorial ACRIBIA S.A. 
Romano, G., Constantiini, M., Lauritano, C. and Ianora, A. 2016.Marine microorganisms as a promising and sustainable source of bioactive molecules. Marine Environmental Research.

Romminger S. 2006. Instituto de Química de São Carlos, Site accessed: $\quad 2007$. http://web2.iqsc.usp.br/iqsc/ensino/spgr/wpcontent /uploads.

Rossman, A. Y., Palm, M. and Spielman, L. J. 1987. A literature guide for the identification of plant pathogenic fungi. St. Paul: APS Press.

Sathiyanarayanan, G., Gandhimathi, R., Sabarathnam, B., Kiran, G. S. and Selvin, J. 2014. Optimization and production of pyrrolidone antimicrobial agent from marine sponge-associated Streptomyces sp. MAPS15. Bioprocess Biosystems Engineering. 37: 561-573.

Silveira, V.D. 1995. Micologia. Fifth ed. Rio de Janeiro: Âmbito Cultural, Brazil.

Solano, G., Jiménez, K., Jaspars, M. and Tamayo, G. 2009. Study of the diversity of culturable actinomycetes in the North Pacific and Caribbean coasts of Costa Rica. Antonie van Leeuwenhoek. 96: 71-78.

Statistical Package for Windows by StatSoft, inc. 1997. Version 5.1, edition.

Suguio, K. 1973. Introdução à Sedimentologia. São Paulo: Edgard Blücher. EDUSP.

Ventura, M., Canchaya, C., Chandra, G.; Fitzgerald, G. F., Chater, K. F. and Sinderen, D. 2007. Genomics of Actinobacteria: Tracing the volutionary History of an Ancient Phylum. Microbiology And Molecular Biology Reviews. 71(3): 495-548.

Wurzbacher, C. M.; Bärlocher, F.; Grossart, H. P. 2010. Fungi in lake ecosystems. Aquatic Microbial Ecology.59:125-149.

Zem, R., Marone, E. and Patchineelam, S. 2005. Sínteses Comparativa de Métodos de Análises Granulométrica de Sedimentos. XXV Congresso de Ciências Del Mar, de Chile y XI Congresso Latino Americano de Ciências Del Mar, Chile.

\section{How to cite this article:}

Mariana Vieira Porsani, Hedda Elisabeth Kolm and Ida Chapaval Pimentel. 2017. First Record of Fungi and Actinobacteria Isolated from the Marine Sediment Collected in the Intertidal Region from an Island Located in the South of Brazil. Int.J.Curr.Res.Aca.Rev. 5(2), 51-60. doi: http://dx.doi.org/10.20546/ijcrar.2017.502.007 